\title{
A MODEL FOR SUSTAINABLE COMPETITIVE ADVANTAGE IMPROVEMENT OF BATIK SMES AT CENTRAL JAVA PROVINCE AND DIY (SPECIAL REGION OF YOGYAKARTA)
}

\section{Erna Indriyaningrum*1 ${ }^{*}$ and Olivia Fachrunnisa*}

\author{
*) Sultan Agung Islamic University \\ Jl. Kaligawe Raya No.KM, RW.4, Terboyo Kulon, Semarang 50112, Indonesia
}

\begin{abstract}
The availablity of Information technology in IR 4.0 demands the ability of SMEs to build a culture to foster competitiveness. This study aims to test a model to improve Sustainability Competitive Advantage based on Innovation Culture, Adaptation Capability and IT Adoption. This type of research uses explanatory research, to test the proposed hypothesis. Data was collected from 106 Batik SMEs owner of Central Java and Yogyakarta through a questionnaire and analysis using SmartPLS. The results shows that SMEs need to strive for the development of an Innovation Culture, in the form of creating new product and services and finding new market opportunities for running their business. Innovation Culture is useful for fostering adaptability in the form of creating change, focusing on services, and developing knowledge. The Innovation Culture that has been formed also has an impact on the ability to apply information technology, namely relative advantage, adaptability, and practicality. Adaptation Capability and Technology Information Adoption that has been formed in SMEs, can help to increase Competitive Advantage so that it continues, marked by increased cost reduction, differentiation and quality.
\end{abstract}

Keywords: sustainable competitive advantage, innovation culture, adaptation capability, technology information adoption

\begin{abstract}
Abstrak: Kemajuan teknologi informasi dan era Revolusi Industri 4.0 menuntut kemampuan UKM membangun budaya yang menekankan keunggulan daya saing. Penelitian ini bertujuan untuk menguji model peningkatan Sustainability Competitive Advantage berbasis Budaya Inovasi, Kemampuan Adaptasi dan Adopsi Teknologi Informasi. Penelitian ini bersifat eksplanatori, yang bertujuan untuk menguji hipotesis yang diajukan. Data dikumpulkan dari 106 UKM Batik di Jawa Tengah dan Yogyakarta melalui kuesioner dan data yang terkumpul di analisis menggunakan SmartPLS. Hasil penelitian menunjukkan bahwa UKM perlu mengupayakan pengembangan Budaya Inovasi berupa penciptaan produk dan layanan baru serta menemukan peluang pasar baru untuk menjalankan usahanya. Budaya Inovasi berguna untuk menumbuhkan kemampuan beradaptasi berupa menciptakan perubahan, fokus pada layanan, dan mengembangkan pengetahuan. Budaya Inovasi yang telah terbentuk juga berdampak pada kemampuan penerapan teknologi informasi yaitu keunggulan relatif, adaptabilitas, dan kepraktisan. Kemampuan Adaptasi dan Adopsi Teknologi Informasi yang telah dibentuk di UKM, dapat membantu meningkatkan keunggulan kompetitif berkelanjutan, ditandai dengan penurunan biaya, diferensiasi dan peningkatan kualitas.
\end{abstract}

Kata kunci: daya saing berkelanjutan, budaya inovasi, kapabilitas adaptasi, adopsi teknologi informasi

\footnotetext{
${ }^{1}$ Alamat Korespondensi:

Email: ernaindriyaningrum14@gmail.com
} 


\section{INTRODUCTION}

The availability of technology from IR 4.0, for example information technology during the post-pandemic period, provides opportunities as well as challenges in maintaining sustainability facing the dynamics of unpredictable change in the business environment. The impact of the Covid 19 crisis, for example, social distance and lockdown regulation put pressure on financial limitations, disrupted operational cash flow, and physical communication with limited customers, resulting in decreased ability to maintain sustainability (Ali and Karimah, 2020). This phernomenon demands the ability of SMEs to build a culture to continue to innovate in order to be able to adapt to changes that are increasingly fast and unpredictable through optimizing the adoption of information technology.

SMEs become the key to achieve an increased national economic development through labourabsorption. Small and medium enterprises dominate most of the business activities in ASEAN. SMEs contributes to increase the people's welfare (The Asia Foundation, 2020). Batik SMEs is one of the small business in the creative industry sector that has contributed to Indonesia's economic development, especially in national income and employment (Trisnaningrum et al. 2014). Indonesian Batik has also received recognition from UNESCO since 2 October 2009 as a cultural heritage (Antara News, 2009). Therefore, it requires attention in order to gain SMEs the competitive advantages and sustainability. One of the determinants of achieving SMEs competitive advantages is through innovation culture building to manage competencies in the use of information technology for their human resources, including owners, leaders, managers and employees. Culture to build of innovation has an important role, because it can drive the level of competency of human resource to be able to adapt and adopt the available information technology (Hidayat et al. 2020).

The success of SMEs in developing and facing global competition in the digital market is determined by the achievement of competitive advantage (Styaningrum et al. 2020). Companies both large and small scale can achieve Sustainable Competitive Advantage (SCA) if they have valueable, scarce, inimitable resources and non-substitable attributes, and only up to the Competitive Advantage (CA) level if they only have valueable attributes and scarce in their resources (Barney, 1991). Technology resources and positioning capability were positively related to SCA results (Huang et al. 2015), consistent with the previous Resource Based View (RBV) proposition that an SCA firm arises from specific resources and has superior capabilities by (Barney, 1991). It can be said that the company's SCA is achieved through its resource position and capabilities, while the company's CA is achieved through its market position.

Several researchers have stated that the most important factor to achieve SCA is by increasing the adaptability and adoption of information technology. Chakrabarty et al. (2014) found that sustainability practices help companies develop opportunities and manage economic, environmental, and social risk, creating value in the long term. Therefore, company adaptation is needed with new development models to deal with various changes and is included in the company's strategy for business decision-making managers that are reflected by changing attitudes, cultures and interests (Mebratu, 1998) because they are related to SCA human resources in organizations (Renwick et al. 2016). Complex and unpredictable environmental changes in sustainability must be passed and re-adapt dynamically over time (Hahn and Aragón-Correa, 2015). (Boylan and Turner, 2017) state that developing an organization that is able to adapt in a dynamic operating environment is an important competency of organizational leaders and an important function of a successful organization.

Research conducted by (Hamad et al.2018) investigating various factors affecting B2B e-commerce adopted by 260 manufacturing MSMES in Egypt suggest that the technology-oganization-environment (TOE) framework factor has a significant impact at various levels B2B e-commerce adoption and has an indirect impact on SCA. The adoption of e-commerce can contribute to the development of MSME business and the development of a country's economy (Ghobakhloo et al. 2011). This because e-commerce is able to provide benefits including reducing cost, facilitating links to global markets and increasing operational efficiency. The success of the information technology adoption process in organizations is influenced by organization culture that emphasized trust, flexibility, innovation, policies, procedured, dan information management as a hierarchical culture (Ruppel and Harrington, 2001). Organizational culture is one of the key elements in increasing and inhibiting the adoption of innovation (Valencia et al. 2010). 
In Indonesia, Central Java and DIY (Special region of Yogyakarta) is known as the center of the batikproducting industry (Siregar et al. 2020). In addition, Central Java Province and DIY are also known as a great potential for the central region of Batik SMEs (Pinasti and Adawiyah, 2016). Is Batik SMEs able to continue to maintain this competitive advantage from time to time or continue to become SCA, as well as Batik SMEs which are not yet capable of catching up and even better than their competitiors' in the future? Most of these Batik SMEs are not aware that a very important and determining resource is in the form of intangible, namely innovation. Leaders who are futureoriented, risk-taking, flexible, open and respect the process of change are urgently needed and continue to carry out the learning process. Furthermore, this culture supports the ability of Batik SMEs to adapt to new environments and is critical of their resources to engage in innovative and creative endeavors.

\section{METHODS}

The respondent of this study were 106 entrepreneurs or owners of Batik SMEs in Central Java province and DIY (Special Region of Yogyakarta) with assumption that the respondents had adopted information technology, especially social media. The data collection method used interview techniques using a questionnaire. All variable indicators are measured using a Likert scale starting from a score of 1 (strongly dissagree one) to 5 (strongly agree).

\section{Measure}

Innovation Culture is defined as a set of policies or rules, attitudes, environmental conditions and organizational factors that enable the growth and development of creativity and innovation in a progressive manner in an organization. Innovation Culture can be measured by three dimensions (new products, new services and new market opportunities), consisting of six indicator items (Morris et al. 1994); (Hult et al. 2004); (Jerez-Gómez et al. 2005).

Adaptation Capability refers to the ability to identify and capitalize opportunities arising from the market, can be measured by the ability to monitor customer and competitor markets and allocate resources for marketing activities (Hofer et al. 2015); (Sriwidadi et al. 2016). The third variable, Information Technology Adoption is a feature used for profitable performance innovations (Martins and Terblanche, 2003). It is measured by three dimensions (relative advantages, compatibility, and simpleness), consisting of six indicators which adapted from (El-Gohary, 2012); (Ghobakhloo et al. 2011); (Ramdani et al. 2009); (Thong, 1998). Meanwhile, we defined Sustainable Competitive Advantage is an advantage over competitors that is achieved by offering greater value to consumers, either through lower prices or by providing more benefits at a higher price (Kotler and Amstrong, 2010). The indicators of Sustainable Competitive Advantage consist of six items which adapted from (Krell and Matook, 2009); (Lumpkin et al. 2002); (Teo and Pian, 2003); (Porter, 2005); (N'Da et al. 2008); (Bhatt and Emdad, 2010); (Moodley, 2003).

This research seeks to improve the Sustainable Competitive Advantage (SCA) of Batik SMEs through Adaptation Capability, technology Information Adoption and Innovation Culture, and wants to find answers about whether Innovation Culture affects Adaptation Capability and Technology Information Adoption? Does Adaptation Capability affect the Sustainable Competitive Advantage? Does the Technology Information Adoption also affect on Sustainable Competittive Advantage? This research uses an explanatory research type that explains the relationship between Innovation Culture, Adaptation Capability, Technology Information Adoption and Sustainable Competitive Advantage. Figure 1 describe the empirical model.

\section{Innovation Culture and Adaptive Capability}

Some of the essential elements for adapting to the company's external environment are mission and strategy, goals, means of developing consensus, reaching goals, measurement, and correction (Schein, 2010). The process of forming an innovative culture in an organization is highly dependent on the characteristics of organizational leaders. According to (Northouse, 2016), the adaptive leadership process integrated four point of view, namely systems, biology, service orientation, and psychotherapeutic perspectives. (Boylan and Turner, 2017); (Derue et al. 2011); (Hannah et al. 1998); (Heifetz et al. 2009); (Northouse, 2016) argues that adaptive leadership has been described as the ability of a leader to gather individuals to solve developing and difficult problems. Hipotesis 1 (H1): Innovation Culture increases Adaptation Capability. 


\section{Innovation Culture and Information Technology Adoption}

Zhu et al. (2012) found that infrastructure, cultural factors strongly influence the decision to adopt e-commerce for companies around the world. (Valencia, Valle and Jime'nez, 2010) suggest that organizational culture is one of the key elements in increasing and inhibiting the adoption of innovation. They found that while adhocratic culture can increase the adoption of innovation, hierarchical culture on the other hand, can inhibit it. Hipotesis $2(\mathrm{H} 2)$ : Innovation Culture has a positive effect on Technology Information Adoption.

\section{Information Technology Adoption and Sustainable Competitive Advantage}

Research on the impact of managerial ability and adaptation by (Ali, Sun and Ali, 2017) found a strong and significant relationship between managerial ability, adaptive ability and organizational innovation. All dimensions of managerial capabilities and adaptive capabilities help develop and improve organizational performance of MSMEs in developing country. Research (Revell et al. 2010) regarding the motivation that encourages MSMEs to adapt is due to the demands of cost savings, finding new customers, higher staff retention and good publication. Hipotesis 3 (H3): Adaptation Capability has a positive effect on Sustainable Competitive Advantage.

\section{Information Technology Adoption and Sustainable Competitive Advantage}

Research related MSMEs in Beijing, China on the adoption of the e-commerce and its impact on business success found that IT investment is the most important factor to achieve success, the competitive advantage can be achieved largely depends on whether the company will effectively use network technology; second, expanding the size of the company can encourage an increase in the volume of MSMEs transactions in the short term; third, internet availability has a positive effect on the volume of e-commerce trade, but the intensity is unclear, and the effect is relatively stable (Chen and Zhang, 2016). In addition, research conducted by (Hamad, Elbeltagi and El-Gohary, 2018), suggesting that the technology-organizationenvironment (TOE) framework factor has a significant impact on various levels of B2B e-commerce adoption and has an indirect impact on competitive advantage. Hipotesis 4 (H4): Technology Information Adoption can increase Sustainable Competitive Advantage.

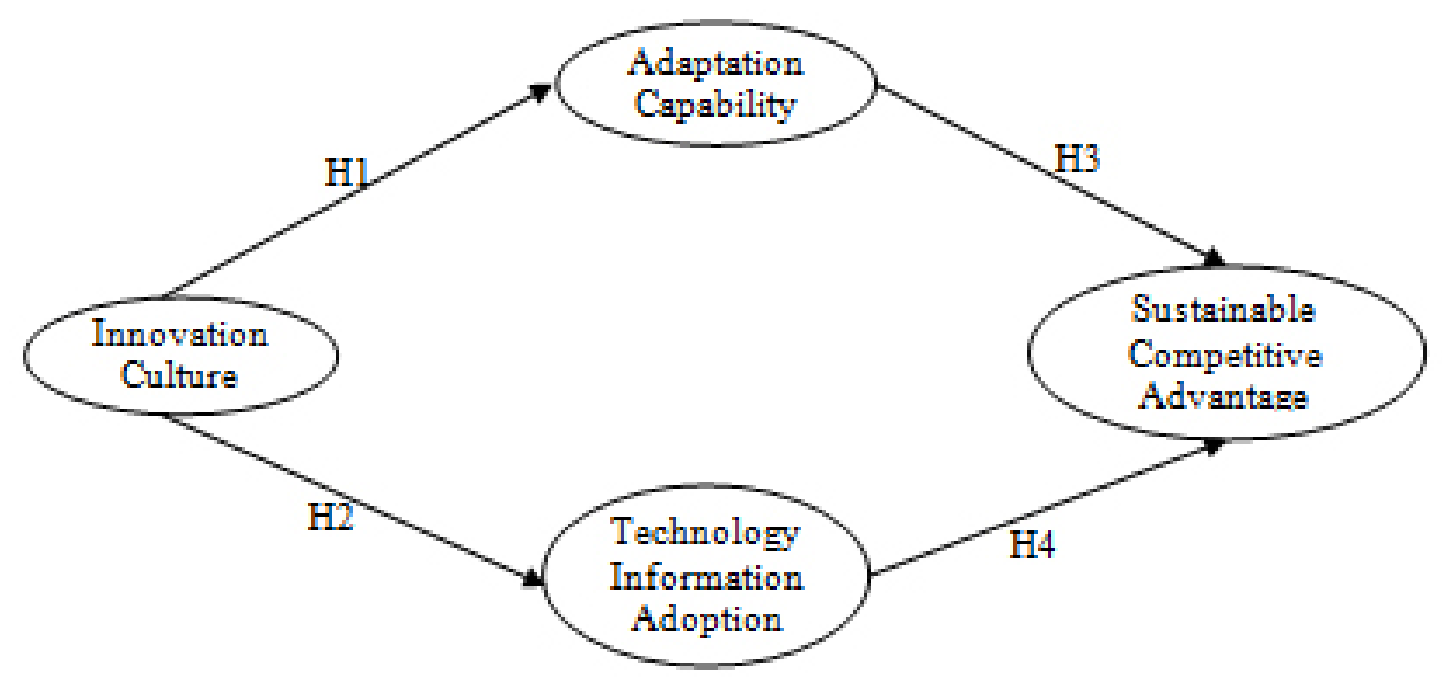

Figure 1. Empirical model 


\section{RESULTS}

\section{Descriptive Respondents and Variables}

Respondent decription obtained $55.1 \%$ dominnat female respondents. The largest educational profile is $\mathrm{S} 1$ (bachelor degree) as much as $43 \%$. The description of the innovation culture variable shows that the respondents' opinions tend to be moderate with a statistical mean of 3.631. The description of the Adaptation Capability variable shows that the respondents' opinions tend to be high with an average od statistical mean of 4.126. The description of the IT Adoption variable shows that the respondents' opinions tend to be high with an average statistical mean of 4.080. Respondents' varied responses indicate that Information Technology Adoption activities have not been fully carried out optimally, not all of them take advantage of the feature that exist in social media and are still combined with offline activities. The result of sustainable competitive advantage shows that respondents' opinions tend to be moderate with a statistical mean 3.748.

\section{Statistical Analysis and Hypothesis Testing}

\section{Measurement Model Evaluation}

This study used Partial Least Squares (PLS) analysis to test the four proposed hypotheses. The software to conduct the analysis is provided by SmartPLS 3 (Ringle, Wende and Becker, 2015). By using this software, the initial stage of PLS analysis with SmartPLS 3, before test measurement model test is to estimate the model which can be pictorially describe in Figure 2.

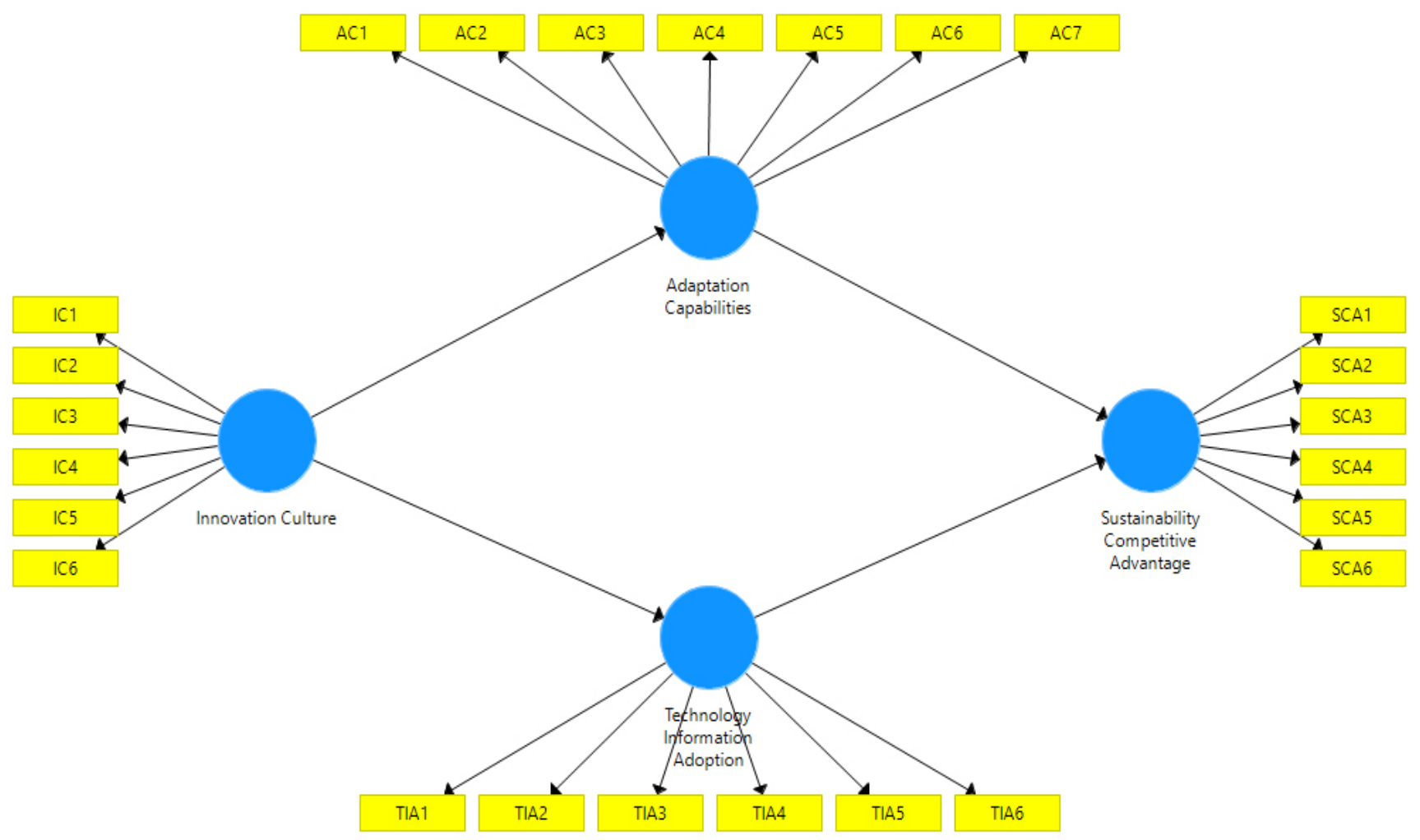

Figure 2. Estimation model 
Evaluation of measurement models is used to test internal consistency (Cronbach alpha and composite reliability); convergent validity (indicator reliability and AVE); and discriminant validity (Fornell-Larcker Criterion, Cross Loading and HTMT). The result of the measurement model assessment is said to be satisfactory if the indicator of the reliability of each item's outer is higher between 0.5 to 0.7 (Hair et al. 2010). If the measurement model result shows the AVE value is less than 0.5 , the composite reliability is higher than 0.6, the convergent of the construction is sufficient (Fornell and Larcker, 1981). The Cronbach alpha value has ranged from 0.40 to 0.60 more than 0.60 to 0.80 ; and more than 0.80 to 1.00 have level of reliability that is quite reliable, reliable, and very reliable (Hair et al. 2010). The results of the discriminant validity test using cross loading have higher loading factors than all coross-loading with other variables. Hence, it can be concluded that the discriminant validity of the measurement models was confirmed. Moreover, the evaluation result of PLS model Algorithm run 1, the outer loading are more than 0.7, showing that all indicators of all variables are valid, then there is no indicators that need to be eliminated. The test results of the measurement model shows that the measurement model is valid and reliable.

\section{Structural Model Evaluation}

The coefficient of determination (Table 1) is used to measure the ability of exogenous constructs (Innovation Culture) in explaining in endogenous variable (Adaptive Capability, Technology Information Adoption and Sustainable Competitive Advantage). The expected $\mathrm{R}^{2}$ value criteria are between 0 and 1 . The result of $R^{2}$ value of all endogenous variables shows ability in predicting the model. The value of $\mathrm{R}^{2} 0.75,0.50$ and 0.25 (Hair et al. 2017) show that the ability of endogenous variables in predicting models is (Strong, moderate, and weak). It can be concluded that Adaptive Capabilities and IT Adoption have weak ability to predict model. Endogen variable of Sustainable Competitive Advantage have
Strong ability in predicting model. It can be said that exogenous variable (Innovation Culture), have ability to predict $(22 \%$, and $12 \%)$ on Adaptation Capabilities and IT Adoption, while the rest is influenced by other variables outside of this research. Furthermore, Innovation Culture, Adaptation Capabilities and IT Adoption, have strong ability to predict $(77 \%)$ on Sustainable Competitive Advantage, while the rest is influenced by other variables outside of this research.

The results of the structural model analysis are shown in Table 2 and Figure 3. The results show the path coefficient along their significance level. Path coefficients describe the strength of relationship between constructs (latent variables). This evaluation is similar to that of the regression coefficients. Analogous to indicator weight analysis, the use of bootstrapping techniques allows for accessing each coefficient's significance (Tenenhaus et al. 2005).

Table 1. Coeffecient of Determination

\begin{tabular}{ll}
\hline Variables & R Square \\
\hline Innovation Culture & \\
Adaptation Capabilities & 0.22 \\
Technology Information Adoption & 0.12 \\
Sustainable Competitive Advantage & 0.77 \\
\hline
\end{tabular}

Although the coefficient of determination endogenous variable of Adaptive Capability and Technology Information Adoption values were weak, the hypothesis test results indicated that all hypotheses were supported. Path coefficient shows that Innovation Culture has a positive and significant effect on Adaptation Capability and Technology Information Adoption. Adaptation Capability and Technology Information Adoption also has a positive and significant effect on Sustainable Competitive Advantage. Hypothesis testing shows that $\mathrm{H} 1, \mathrm{H} 2, \mathrm{H} 3$ and $\mathrm{H} 4$ were supported. Diamantopoulos et al. (2005) categorized path coefficients that are under 0.30 as the causing moderate (effects), from 0.30 to 0.60 as strong, and up to 0.60 as very strong.

Table 2. Path Coefficient

\begin{tabular}{lllll}
\hline Path & $\beta$ & SD & t-value & Hypotheses \\
\hline Innovation Culture --> Adaptation Capabilities & 0.47 & 0.01 & $5.48^{*}$ & Supported \\
Innovation Culture --> Technology Information Adoption & 0.37 & 0.09 & $3.92^{*}$ & Supported \\
Adaptation Capabilities --> Sustainable Competitive Advantage & 0.49 & 0.11 & $4.62^{*}$ & Supported \\
Technology Information Adoption --> Sustainable Competitive Advantage & 0.42 & 0.10 & $3.85^{*}$ & Supported \\
\hline
\end{tabular}

* $\rho$-value $<0.05$ 


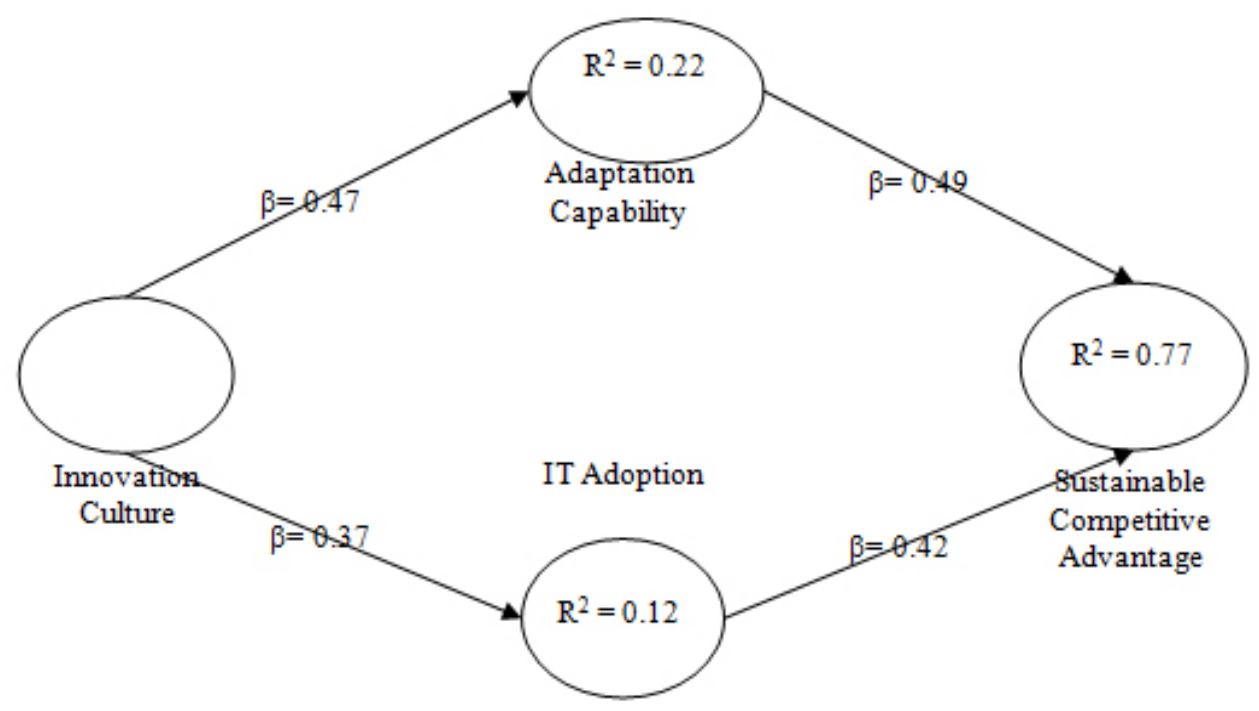

Figure 2. Structural model

The results of this study indicate that the model is fit with data, and all hypotheses are supported. Batik SMEs tent to advocate new product ideas and creativity, new services and seek new market opportunties at a moderate level. Batik SMEs strives to always be open and appreciate innovative ideas and creativity for these things and is always committed to fostering the behavior or habits of all employees involved in it, so that it has a positive and significant impact on adaptation capability. The adaptability of Btik SMEs tends to be high which strives to create change, focus on customers and increase knowledge and company development. They try to always do everything flaxibly and easily, always give a positive response to competitors, the team and employees always work together to create change. Customer comments and suggestions are an evaluation material for the company, all teams and employees underatand customer wants and needs, all of which are encourages to build good relationships with customers as an effort to focus on customers. In addition, Batik SMEs views failure as an opportunity to learn ans as a material for improvement. The team and employee learning process is considered a key factor in the success of SMEs as an effort to increase knowledge and develop their capabilities.

The level of Innovation Culture of batik SMEs tends to be influencing the level of Technology Information Adoption which tends to be high. The culture of innovation in seeking the creation of new products, services and market opportunities, encourages them to adopt e-commerce on the grounds that e-commerce can provide relative advantage, suitability and practically. By adopting e-commerce, it is more profitable economically because it can reduce the cost of promotion and sales than offline, the use of time become more efficient because it is faster. The adoption of e-commerce is more in line with their Batik SMEs because they are in line with the changing times and needs of the customers, and in accordance with SMEs' corporate beliefs in achieving their vision and mission. E-commerce adoption is more practical or simpler because it is more flexible and easier to learn and use

The adaptability of Batik SMEs tend to be higher in an effort to create change, focus on customer, increase knowledge and develop the capabilities of SMEs that can positively and significantly affect differentiation, and moderate quality. Produce product at competitive prices in the market compared to competitiors' products, and are able to reduce marketing, advertising, branding and sales costs in an effort to reduce costs. Differentiation is pursued through efforts to make products and services unique, so that competitiors cannot imitate them, Batik SMEs product and services can meet customer needs or problem solutions and cannot be replaced by competitor products or services. The quality of products and services is pursued by having tighter, stronger, more durable or reliable specifications, and Batik SMEs are able to provide better, cheaper, faster and more accurate information and services to customers.

Adoption of Information technology, in this case e-commerce of Batik SMEs, tend to be high and can positively and significantly influence sustainable competitive advantage in terms of cost reduction, differentiation, and moderate quality. By adopting e-commerce, products and services that are superior, 
competitive and sustainable can be created. The reasons for relative advantages, sustainability and practically in adopting e-commerce support Batik SMEs efforts in reducing costs, differentiation and achieving quality products and services that are able to achieve sustainable competitive advantage.

\section{Managerial Implications}

This study succeeded in obtaining empirical evidence that all variables in the hypotheis had a positive and significant effect. Therefore, several managerial implications can be provided based on statistical data. First, it is better for SMEs owber to establish a marketing strategy that aims to communicate product information to consumers that all teams and employees can do. The product information starts from the details and advantages of the product, and its features. Understanding of marketing is actually not just selling products. Marketing is the activity of marketing a product or service is known by the market. Marketing is the entire system of business activities aimed at planning products, setting prices, promoting products and distributing goods aimed at satisfying consumers. Sales are sales activities carried out where these activities cover techniques, tactics, that art relationship and the art of communication between salespeople and prospective customers. Sales activities aim to increase product sales only. Second, we suggest Batik SMEs to always conduct market surveys, compare, analyze the factors needed, know who are competitors, what products can compete, and know how to market it. Strategy to build relationships with consumers, consumers handling is very important and must be done by all teams and employees of Batik SMEs. This is as an effort to find out what the desired and how consumers behave so that they feel comfortable and loyal.

Thirdly, a strong vision and mision must be established in advance as a basis for what steps the company must prepare in running its business. Having a business vision can help determine the direction in developing a business, clarity of vision makes the business stronger. A vision is the goal of a journey that has been mapped so that it is clear where it is going. The vision is made by looking at the goals itself, not the short term, but the long term that will be achieved. Meanwhile, the mission is a process and steps to achieve the content and preparation needed. The mission is dynamic and can be revised according to business development and situations. The vision and mission must have the drive to make it happen, have an appeal so that all those involved in the business have the same passion and commitment to make it happen. The vision and mission must also be realistic, have the possibility to be achieved and have the power to anticipate future changes.

\section{CONCLUSIONS AND RECOMENDATIONS}

\section{Conclusions}

The results of this hypothesis indicate that the Innovation Culture has a positive and significant effect Adaptation Capability. The results of this study are in the line with the results of previous research conducted by (Schein, 2010) which states that the process of forming a strong organizational culture of innovation in the long term will survive in adapting to the external environemnt. The results of this study are also in line with (Heifetz, Kania and Kramer, 2004); (Northouse, 2016) that the adaptive leadership process requires a process of learning new ways to adapt to organizational change.

The second hypothesis (H2) are also supported, where the adoption of a culture of innovation by Batik SMEs will be able to create and increase the adoption of information technology. The results of this study are in line with the results of previous studies by (Ruppel and Harrington, 2001) culture in organizations is identified as an important factor in the success or failure of information technology adoption in organizations, innovation culture facilitates the factors affecting intranet adoption. The results of research (Valencia, Valle and Jime'nez, 2010) suggest that a culture of innovation in organizations is one of the key elements in increasing and can also hinder the adoption of innovation. Morover, the third hypothesis (H3) are supported, by which the adaptation capability of Batik SMEs will create and increase sustainable competitive advantage. The results of this study are in line with the results of research (Revell et al. 2010), regarding the motivation that encourages SMEs to adapt is due to the demands of cost savings, finding new customers, higher staff retention and good publication.

The fourth hypothesis (H4) test results are indicating that if Batik SMEs can adopt these external motives, it will enhance the corporate image of Batik SMEs and position of the competitiveness or effectiveness of management practices, customer demand and 
requirements to compete in certain sectors (HerasSaizarbitoria et al. 2006); (Heras-Saizarbitoria et al. 2011); (Adair and Jaeger, 2016); (Gómez-López et al. 2019). The results of this study are in line with the results of research by (Chen and Zhang, 2016) that IT (Information Technology) investment is the most important factor in achieveing business success. The competitive advantage that can be achieved depends largely on whether the SMEs will effectively use network technology and the expansion of the size of the business (from SMEs to larger scale business). Batik SMEs can encourage an increase in their transaction volume in the short term and the availability of the internet has a positive effect on the volume of e-commerce trading.

\section{Recomendations}

This study aims to determine the effect of existing variables on sustainable competitive advantage in Batik SMEs at Central Java province and DIY (Special Region of Yogyakarta). However, by looking at the research background, theoretical justification and research methods, it can be conveyed that the limitations of this research are absence of a factual measure of how far sustainable competitive advantage has been achieved. Competitive advantage is measured only based on the respondent's recognition as the owner or an actor of Batik SMEs, but only limited to the achievements during the last 3 (three) years until the data collected in this research questionnaire. The use of a questionnaire in this study has several weaknesses, including selfreporting techniques that are prone to responses that contain errors (response errors). Error responses can also be caused by individuals who are inconsistent in filling out the questionnaire, because they refer to other references besides those directed by the questionnaire (Biderman and Reddock, 2012). From the participant's point of view, there are three factors that cause error response that many researchers have studied, namely response style, response rules (response set) and response bias. Response style describes how individuals respond to items in a questionnaire with a unique pattern and tend to be consistent (Weijters et al. 2010).

This uniqueness can be seen from the participants who filled out the questionnaire with reference to other criteria than the contents of the questionnaire (Van Herk, Poortinga and Verhallen, 2004). In addition to the response style which is relatively stable, there are also individual ways of responding related to the situation at hand, time pressure and measurement techniques used. This method is called a response rule (response set). Bias response is "a systematic tendency to respond to a range of questionnaire items on some other basis than the specific item content" (Paulhus, 1991). Further research can be done by looking at the limitation that exist in this study that requires a more in-dept measurement of the extent to which the variable of sustainable competitive advantage is echieves in Batik SMEs. In addition, further research is needed by adding additional indicators that are more supportive, such as the achievement of sales targets, an increase in the number of customers, an increase in international market demand and the need for confirmation of secondary data from other parties or sources.

\section{REFERENCES}

Adair D, Jaeger M. 2016. Incorporating critical thinking into an engineering undergraduate learning environment. International Journal of Higher Education 5(2): 23-39.

Al-Qirim N. 2006. Personas of e-commerce adoption in small businesses in New Zealand. Journal of Electronic Commerce in Organizations 4(3): $18-45$.

Ali N, Karimah V. 2020. The fourth industrial revolution, pandemics, and the future of work. The ASEAN Magazine. https://asean.org/aseansocio-cultural/.

Ali Z, Sun H, Ali M. 2017. The impact of managerial and adaptive capabilities to stimulate organizational innovation in SMEs: A complementary PLSSEM approach. Sustainability 9(12).

Antara News. 2009. UNESCO Setujui Batik Sebagai Warisan Budaya Indonesia. Antara News.com. https://www.antaranews.com/berita/153756/ unesco-setujui-batik-sebagai-warisan-budayaindonesia. [Accessed: 4 November 2015].

Barney J. 1991. Firm reources ad sustained competitive advantege. Journal of Management 17(1): 99120.

Bhatt GD, Emdad AF. 2010. An empirical examination of the relationship between information technology (IT) infrastructure, customer focus, and business advantages. Journal of Systems and Information Technology 12(1): 4-16. http:// dx.doi.org/10.1108/13287261011032625.

Biderman MD, Reddock CM. 2012. The relationship of scale reliability and validity to respondent inconsistency. Personality and Individual 
Differences 52(5): 647-651. http://dx.doi. org/10.1016/j.paid.2011.12.012.

Chakrabarty S, Widing RE, Brown G. 2014. Selling behaviours and sales performance: The moderating and mediating effects of interpersonal mentalizing. Journal of Personal Selling and Sales Management 34(2): 112-122.

Chen B, Zhang J. 2016. Analytics for knowledge creation: towards epistemic agency and designmode thinking. Journal of Learning Analytics 3(2): 139-163. http://dx.doi.org/10.18608/ jla.2016.32.7.

Derue DS et al. 2011. Trait and behavioral theories of leadership: An integration and meta-analytic test of their relative validity. Personnel Psychology, 64(1):7-52.

Diamantopoulos A, Riefler P, Roth K. 2005. The problem of measurement model misspecification in behavioral and organizational research and some recommended solutions. Journal of Appyled Psychology 90: 710-730.

El-Gohary H. 2012. Factors affecting E-Marketing adoption and implementation in tourism firms: An empirical investigation of Egyptian small tourism organisations. Tourism Management. Elsevier Ltd, 33(5): http://dx.doi.org/10.1016/j. tourman.2011.10.013.

Fornell C, Larcker DF. 1981. Evaluating structural equation models with unobservable variables and measurement error. Journal of Marketing Research 18(1): 39-50. https://doi. org/10.2307/3151312.

Ghobakhloo M. et al. 2011. Information technology adoption in small and medium-sized enterprises; an appraisal of two decades literature. Interdisciplinary Journal of Research in Business 1(7): 53-80.

Gómez-López M, Viejo C, Ortega-Ruiz R. 2019. Psychological well-being during adolescence: Stability and association with romantic relationships. Frontiers in Psychology 10(JULY): 1-13.

Grandon E, Pearson J. 2004. Electronic commerce adoption: An empirical study of small and medium US businesses. Information and Management 42(1): 197-216.

Hahn T, Aragón-Correa JA. 2015. Toward cognitive plurality on corporate sustainability in organizations: the role of organizational factors. Organization and Environment 28(3): 255-263.

Hair JF et al. 2010. Multivariate Data Analysis. 7th edn. Upper Saddle River, NJ: Prentice Hall.

Hair JF et al. 2017. A Primer on Partial Least Squares

Structural Equation Modeling ( PLS-SEM).

Second Edi. Los Angeles: SAGE Publicstion.

Hamad H, Elbeltagi I, El-Gohary H. 2018. An empirical investigation of business-to-business e-commerce adoption and its impact on SMEs competitive advantage: The case of Egyptian manufacturing SMEs. Strategic Change 27(3): 209-229.

Hannah ST, Woolfolk RL, Lord RG. 1998. Leader selfstructure: a framework for positive leadership SEAN. Journal of Marriage and Family 60(1): 5-22.

Heifetz RA, Grashow A, Linsky M. 2009. Leadership in a (Permanent) Crisis. Harvard Business Review. https://hbr.org/2009/07/leadership-in-apermanent-crisis.

Heifetz RA, Kania JV, Kramer MR. 2004. Leading Boldly: Foundations can move past traditional approaches to create social change through imaginative-and even controversial-leadership. Stanford Social Innovation Review (21-31).

Heras-Saizarbitoria I, Casadesús M, Marimón F. 2011. The impact of ISO 9001 standard and the EFQM model: The view of the assessors. Total Quality Management and Business Excellence 22(2): 197-218.

Heras-Saizarbitoria I, Landín GA, Fa MC. 2006. The impact of quality management in European companies' performance: The case of the Spanish companies. European Business Review 18(2): 114-131. doi: 10.1108/09555340610651839.

Van Herk H, Poortinga YH, Verhallen TMM. 2004. Response styles in rating scales: Evidence of method bias in data from six EU countries. Journal of Cross-Cultural Psychology 35(3): 346-360.

Hidayat $\mathrm{N}$ et al. 2020. COMPETENCY-BASED HUMAN RESOURCE MANAGEMENT MODELINTHE INDUSTRIALERA4.0. Jurnal Aplikasi Manajemen dan Bisnis 6(3): 501-513. http://dx.doi.org/10.17358/jabm.6.3.501.

Hofer KM, Niehoff LM, Wuehrer GA. 2015. The effects of dynamic capabilities on value-based pricing and export performance. Entrepreneurship in International Marketing 25: 109-127. https:// doi.org/10.1108/S1474-797920140000025005.

Huang KF et al. 2015. From temporary competitive advantage to sustainable competitive advantage. British Journal of Management 26(4): 617-636. 
Hult GTM, Hurley RF, and Knight, G. A. (2004) Innovativeness: Its antecedents and impact on business performance. Industrial Marketing Management 33(5): 429-438.

Jerez-Gómez P, Céspedes-Lorente J, Valle-Cabrera R. 2005. Organizational learning capability: A proposal of measurement. Journal of Business Research 58(6): 715-725.

Khemthong S, Roberts LM. 2006. Adoption of Internet and Web Technology for Hotel Marketing: A Study of Hotels in Thailand. Journal of Business Systems, Governance and Ethics 1(2): 51-70.

Kotler P, Amstrong G. 2010. Principles of Marketing. 13th edn. New Jersey: Pearson Prentice Hall.

Krell K, Matook S. 2009. Competitive advantage from mandatory investments: An empirical study of Australian firms. Journal of Strategic Information Systems. Elsevier B.V. 18(1): 3145. http://dx.doi.org/10.1016/j.jsis.2008.12.001.

Lumpkin GT, Droege SB, Dess GG. 2002. E-commerce strategies: Achieving sustainable competitive advantage and avoiding pitfalls. Organizational Dynamics 30(4): 325-340.

MacGregor RC, Vrazalic L. 2005. A basic model of electronic commerce adoption barriers: A study of regional small businesses in Sweden and Australia. Journal of Small Business and Enterprise Development 12(4): 510-527. http:// dx.doi.org/10.1108/14626000510628199.

Martins EC, Terblanche F. 2003. Building organisational culture that stimulates creativity and innovation. European Journal of Innovation Management 6(1): 64-74. https://doi. org/10.1108/14601060310456337

Mebratu D. 1998. Sustainability and sustainable development: Historical and conceptual review. Environmental Impact Assessment Review 18(6): 493-520.

Mirchandani D, Motwani J. 2001. End-user perceptions of ERP systems: a case study of an international automotive supplier. International Journal of Automotive Technology and Management 1(4): 416-424.

Moodley S. 2003. E-commerce and export markets: Small furniture producers in South Africa. Journal of Small Business Management 41(3): 317-324.

Morris MH, Davis DL, Allen JW. 1994. Fostering corporate entrepreneurship: cross-cultural comparisons of the importance of individualism versus collectivism. Journal of International
Business Studies 25(1): 65-89. http://www.jstor. org/stable/154852.

N'Da K, Bergeron F, Raymond L. 2008. Achieving advantages from business-to-business electronic commerce: an empirical validation of an integrative framework. International Journal of Electronic Business 6(5): 516-594.

Northouse PG. 2016. Leadership: Theory and Practice. Thousand Oaks, CA: SAGE Publications.

Paulhus DL. 1991. Measurement and Control of response bias. in Measures of Personality and Social Psychologycal attitudes. San Diego, CA: Academic Press.

Pinasti M, Adawiyah WR. 2016. Co-opetition to promote growth of batik small and medium enterprises. International Journal of Business and Society 17(3): 401-412.

Porter QA. 2005. Internet and Competitive advantage: an empirical study of UK banking sector [Dissertation]. The University of Warwick. http://go.warwick.ac.uk/wrap/2846.

Ramdani B, Kawalek P, Lorenzo O. 2009. Predicting SMEs' adoption of enterprise systems. Journal of Enterprise Information Management 22(1): $10-24$.

Renwick DWS et al. 2016. Contemporary developments in Green (environmental) HRM scholarship. International Journal of Human Resource Management 27(2): 114-128. http://dx.doi.org/ 10.1080/09585192.2015.1105844.

Revell A, Stokes D, Chen H. 2010. Small businesses and the environment: Turning over a new leaf? Business Strategy and the Environment 19(5): 273-288.

Ringle CM, Wende S, Becker JM. 2015. SmartPLS 3, Boenningstedt: SmartPLS GmbH. http://www. smartpls.com.

Rogers EM. 1995. The Diffusion of Innovations. 4th edn. New York: Free Press.

Ruppel CP, Harrington SJ. 2001. Sharing knowledge through intranets: A study of organizational culture and intranet implementation. IEEE Transactions on Professional Communication 44(1): 37-52.

Schein EH. 2010. Organizaorganizationaltional Culcultureture Andand Leadership. 4th edn. San Francisco, CA: Jossey-Bass.

Siregar AP et al. 2020. Batik Industry Development Effort In Indonesia. Dinamika Kerajinan Batik: Majalah Ilmiah 37(1): 79-92.

Sriwidadi $\mathrm{T}$ et al. 2016. Sustainable competitive 
advantage in private higher education institutions in Indonesia. International Journal of Economics and Management 10(SpecialIssue1): 33-47.

Styaningrum F, Soetjipto BE, Wulandari D. 2020. THE DETERMINANTS OF SMEs ' SUSTAINABILITY. Humanities \& Social Science Reviews 8(4): 422-430. https://doi. org/10.18510/hssr.2020.8441.

Tenenhaus $\mathrm{M}$ et al. 2005. PLS path modeling. Computational Statistics \& Data Analysis48(1): 159-205.

Teo TSH, Pian Y. 2003. A contingency perspective on Internet adoption and competitive advantage. European Journal of Information Systems 12(2): 78-92.

The Asia Foundation 2020. Factsheet - Go Digital ASEAN : Digital skills to address the economic impact of COVID-19, Go Digital ASEAN. San Francisco, CA, USA. https://asiafoundation. org/publication/factsheet-go-digital-aseandigital-skills-to-address-the-economic-impactof-covid-19/. [3 Nov 2020].

Thong JYL. 1998. An integrated model of information systems adoption in small businesses. Journal of Management Information Systems 15(4): 187214.

Trisnaningrum D et al. 2014. Usaha Kecil Menengah. Widzatiannisa.Wordpress.com. https:// widzatiannisa.wordpress.com/2014/04/21/24/.

Valencia JCN, Valle RS, Jime'nez DJ. 2010. Organizational Culture as Determinant of Product Innovation. Journal of Education 13(4): 466-480. https://doi.org/10.1108/JEA-06-20130067.

Weijters B, Geuens M, Schillewaert N. 2010. The individual consistency of acquiescence and extreme response style in self-report questionnaires. Applied Psychological Measurement 34(2): 105-121.

Zhu Y, Wittmann X, Peng MW. 2012. Institution-based barriers to innovation in SMEs in China. Asia Pacific Journal of Management 29(4): 11311142. 